\title{
PENGARUH KOMUNIKASI NCTZEN INDONESIA TERHADAP PERILAKU MEMILIH NCT DREAM
}

\author{
Aniek Irawatie ${ }^{(1)}$, Indah Purnama Sari ${ }^{(2)}$, dan Retno Dyah Kusumastuti ${ }^{(3)}$ \\ IImu Komunikasi, FISIP Universitas Pembangunan Nasional "Veteran”Jakarta \\ JI. Rs. Fatmawati, Pondok Labu, Jakarta Selatan, DKI Jakarta, I2450, Indonesia \\ Email: (I) irawatieaniek68@gmail.com, (2)indah.baekhyun@yahoo.com, (3) rdnino@gmail.com
}

\begin{abstract}
Abstrak
Social media is a social change tool using the internet where social media used by everyone as their communication process that reaches all levels of society to form a group to talk about something that is in common with the group. NCTzen Indonesia is a fan group from the Kpop idol group, NCT Dream that formed from the social media Twitter, nctconfess. The nctconfess followers are considered to be able to influence the activities and behavior of other followers. This research aims to determine the effect of NCTzen Indonesia's communication through twitter on the voting behaviour fellow followers using the S-O-R theory as its foundation. This research uses a quantitative approach with a survey method or questionnaires spreaded through menfess to 100 respondents in the category of followers of Nctconfess and vote NCT Dream during the promotion period. The results based on the correlation test show that there is a strong relationship between NCTzen Indonesia's communication with voting behaviour. Referring to the test results of the coefficient of determination, shows the magnitude of the effect generated by the Communication of NCTzen Indonesia $(X)$ on the Voting Behavior $(Y)$ is $39.81 \%$ and the remaining $60.19 \%$ is influenced by other factors outside this research.
\end{abstract}

Keywords : NCTzen, NCT Dream, Voting Behavior, Twitter, Kpop

\section{PENDAHULUAN}

Internet merupakan hasil dari perkembangan teknologi masa kini. Berkat teknologi ini, menjadikan proses komunikasi sebagai media perantara antarmanusia. Dalam dunia komunikasi kita mengenal istilah new media dimana istilah ini mengartikan penggunaan internet. Media baru adalah alat yang digunakan untuk berkomunikasi dengan jaringan telekomunikasi digital atau internet yang penggunaannya bisa menjangkau seluruh lapisan masyarakat. Seiring berjalannya waktu, internet ini penggunaannya berubah menjadi suatu kebutuhan yang setidaknya harus dipenuhi bagi sebagian besar masyarakat. Proses pengiriman informasi menjadi sangat mudah bagi siapapun, maka dari itu, informasi yang menjadi kebutuhan setiap orang bisa dengan cepat diperoleh melalui internet sehingga semua orang sangat begantung pada internet untuk era ini.

Berbicara mengenai internet pasti merujuk pada penggunaan media sosial. Di era millennial seperti sekarang, gadget dan media sosial adalah teman akrab untuk masyarakat. Hampir setiap orang memiliki waktu sedikitnya 3 jam dalam sehari untuk menghabiskan waktu dengan gadget ataupun media sosial. Pada dasarnya media sosial diciptakan untuk mempersempit jarak antar manusia untuk berkomunikasi. Dengan adanya media sosial dan internet, jarak dan waktu bukan menjadi halangan untuk berkomunikasi. 
Media sosial memiliki beragam jenis dan fungsinya mulai dari facebook, twitter, instagram, youtube, path, dan lain sebagainya. Salah satu contoh dari media sosial yang akrab digunakan oleh sebagian besar masyarakat adalah Twitter. Twitter merupakan platform media sosial yang berbasis foto dan video serta tulisan. Sejak awal mula Twitter dimunculkan hingga sekarang pengguna media sosial ini semakin meningkat dan kegunaan media sosial ini tidak lagi sebagai jejaring sosial yang berguna untuk berhubungan dengan orang saja namun juga sebagai alat untuk promosi dan branding.

Twitter tidak hanya digunakan seseorang menjadi milik pribadi tetapi banyak ditemukan akun twitter yang bertujuan untuk membangun komunitas, virtual group, akun perusahaan, bahkan akun bisnis. Berdasarkan artikel dari website kamustDi Twitter ada yang namanya istilah autobase, autobase berasal dari kata "auto" dan "fanbase" yang artinya adalah akun fanbase atau base yang sistemnya automatic (otomatis) untuk menyediakan layanan Direct Messages yang secara otoatis muncul di beranda akun twitter autobase tersebut. Cara kerja akun autobase ini adalah dengan mengirimkan konten melalui direct message dengan menggunakan keyword tertentu yang kemudian konten tersebut secara otomatis terunggah di beranda autobase tersebut. Besarnya pengaruh twitter dalam kehidupan komunikasi memberikan dampak signifikan dalam proses komunikasi manusia. Untuk sekarang, media sosial menjadi alat untuk proses komunikasi, branding bahkan promosi dalam hal apapun termasuk industri hiburan.

Industri hiburan merupakan salah satu industri yang paling banyak diminati oleh masyarakat dalam memenuhi kebutuhan untuk menyenangkan secara fisik, mental maupun emosional. Salah satu industri hiburan yang sangat diminati adalah music, di antaranya adalah Kpop atau Korean pop agenre musik pop yang asalnya dari Korea Selatan. Kpop hadir berkat adanya pengaruh Korean Wave di Indonesia. Korean Wave adalah makna dari entertainment Korea yang melintasi Asia dan belahan dunia lainnya. Berdasarkan situs resmi Korea www.korea.net/AboutKorea Penyebaran Korean Wave tidak hanya bidang entertainment dan musiknya saja melainkan budaya, literature, makanan, hingga bahasa. Korean Wave melahirkan musisi-musisi yang digandrungi masyarakat seluruh dunia, tak terkecuali Indonesia.

Musisi asal Korea pada umumnya melakukan promosi lagu yang baru di rilis melalui program musik mingguan, Salah satunya adalah SBS The Show yang tayang setiap hari Selasa yang di akhir acara ada pengumuman pemenang tangga musik mingguan. Kemenangan sebuah grup ketika melakukan masa promosi dinilai berdasarkan kriteria tertentu dan salah satunya berdasarkan voting. Salah satu sub unit NCT yakni NCT Dream berkesempatan untuk melakukan promosi di SBS The Show di pertengahan Agustus 2019. Kemenangan NCT Dream pada acara music mingguan tak terlepas dari hasil voting yang dilakukan melalui media sosial. Salah satu dampak untuk NCT Dream adalah saat NCTzen saling berkomunikasi melalui twitter nctconfess untuk mengajak voting bersama di minggu promosi NCT Dream. Dengan sender yang anonim namun tetap saling berkomunikasi secara intens, berbagi link website ataupun tutorial voting dan sama-sama melakukan voting di minggu promosi NCT Dream hingga NCT Dream dapat memenangkan lagunya di acara music SBS The Show.

Dari uraian tesebut, menarik untuk diketahui apakah komunikasi NCTzen Indonesia mempengaruhi perilaku memilih. Jika ada, perlu ditentukan seberapa besar pengaruh komunikasi NCTzen Indonesia terhadap perilaku memilih. Untuk itu, penelitian ini bertujuan untuk menjawab kedua pertanyaan tersebut. 


\section{Studi Pustaka dan Kajian Teori}

Menurut Deddy Mulyana dalam bukunya Ilmu Komunikasi suatu Pengantar mengatakan bahwa "komunikasi sebagai proses satu arah yang memfokuskan pada penyampaian pesan secara efektif dan menjelaskan bahwa kegiatan komunikasi bersifat persuasif'. Komunikasi juga dipahami sebagai suatu bentuk komunikasi interaksi, yaitu komunikasi dengan proses sebab-akibat atau aksi-reaksi yang arahnya bergantian.

Rohim (2016) menyebutkan bahwa banyak pakar komunikasi mengklasifikasikan komunikasi berdasarkan konteksnya. Konteks atau tingkatanya dibagi berdasarkan jumlah peserta yang terlibat dalam proses komunikasi salah satunya adalah komunikasi kelompok.

Komunikasi Kelompok menurut Maulana dan Gumelar dalam bukunya Psikologi Komunikasi dan Persuasi (2013) mengatakan bahwa komunikasi kelompok adalah komunikasi yang berlangsung antara individu dengan kelompok, kelompok dengan kelompok. Dewasa ini, perkembangan internet membuat proses komunikasi semakin luas hingga dalam prosesnya, penggunaan internet sangatlah vital sehingga proses komunikasi pun dapat dilakukan melalui internet atau yang biasa kita sebut cyberspace communication atau komunikasi virtual. Adanya penggunaan internet melalui media sosial telah menghadirkan sebuah web forum yang dapat membentuk suatu kelompok virtual (Hermawan dalam Nanda, 2018).

Kelompok virtual adalah sekumpulan pengguna internet yang membentuk jaringan hubungan personal. Porter tahun 2004 (dalam Bensa, 2015) mendefinisikan kelompok virtual sebagai kumpulan individu atau rekan yang berinteraksi seputar minat yang sama dan didukung oleh teknologi. Kelompok virtual ini dapat terbentuk dengan media sosial salah satunya twitter.

Twitter didefinisikan sebagai media digital yang menguatkan hubungan sosial berdasarkan komunikasi diantara penggunanya. Twitter mempertahankan dan meluaskan jaringan sosial serta memfasilitasi dalam berbagi informasi. Maka demikian twitter menjadi media penting dalam menyebarkan Korean Wave melalui diskusi publik tiap harinya. Tak terkecuali NCTzen Indonesia yang membentuk komunitas atau kelompok melalui akun twitter nctconfess sebagai sarana berbagi informasi dan diskusi setiap harinya.

Fandom adalah sebutan untuk kelompok penggemar yang menyukai salah satu grup. Tiap fandom dari masing-masing grup memiliki identitas diri masing-masing mulai dari nama fandom, yel-yel fandom, bahkan warna official untuk fandom mereka. Contohnya untuk Grup NCT Dream, para penggemar NCT Dream menamai diri mereka NCTzen dengan warna official hijau rumput atau hijau neon. NCTzen diseluruh dunia saling terkoneksi satu sama lain melalui fanbase yang diakses melalui internet. Untuk di Indonesia sendiri NCTzen saling berkomunikasi untuk mendapatkan informasi terbaru mengenai NCT Dream dan menunjukkan dukungan mereka melalui media sosial salah satunya adalah twitter. NCTzen Indonesia melalui twitter nctconfess sama-sama mengajak untuk melakukan voting di masa promosi NCT Dream agar NCT Dream dapat memenangkan tangga lagu di acara music SBS The Show.

Komunikasi virtual adalah cara berkomunikasi dimana penyampaian dan penerima pesan dilakukan melalui jaringan internet. Komunikasi virtual adlah berbagai jenis program aplikasi yang digunakan untuk melakukan komunikasi antar dua orang atau lebih yang slaing berinteraksi dengan jaringan digital dan internet. Pixy Ferris (dalam Sosiawan, 2011) mendefinisikan komunikasi bermedia internet sebagai "interaksi secara interpersonal yang dihubungkan oleh computer yang meliputi komuikasi asynchronous dan synchcronous melalu fasilitas dalam internet". 
Perilaku Memilih menurut Littlejohn tahun 2009 yang dikutip Abadi dan Putri (2016) mengatakan bahwa setiap individu dalam melakukan perbuatan dilandasi oleh suatu alasan dan keyakinan tertentu. Beberapa factor yang mempengaruhi individu untuk memilih dapat dipengaruhi karakteristik individu itu sendiri atau media massa. Newman dan Sheth (1985) mengembangkan model perilaku memilih ditentukan oleh model yang mempengaruhinya antara lain perasaan emosional dan citra kandidat.

E-Voting merupakan pemanfaatan perangkat elektronik untuk lebih mendukung kelancaran proses dan juga model otomatisasi yang memungkinkan campur tangan minimal dari individu dalam prosesnya (Smith and Clark dalam priyono dan Dihan, 2010). I-voting adalah proses serupa e-voting tapi memanfaatkan teknologi komunikasi dan jaringan internet oleh karena itu, i-voting terkait dengan system online.

Untuk memperjelas arah penelitian maka peneliti menggunakan teori S-O-R sebagai dasar dalam penelitian ini. Teori Stimulus-Organisme-Respon yang kemudian disingkat S-O-R ditemukan oleh Hovland (1953). Teori ini berkenaan berkenaan dengan perubahan sikap dalam proses komunikasi. Dalam teori ini perubahan sikap dapat berubah jika ada stimulus menerpa komunikan. Kualitas dari sumber komunikasi sangat menentukan perubahan perilaku seseorang, kelompok atau masyarakat. Dalam menelaah sikap yang baru ada tiga variable yang menjadi komponen yaitu perhatian, pengertian, penerimaan. Effendy tahun 2003 (dalam Kurniawan, 2018) menjelaskan unsur penting dalam model komunikasi S-O-R yaitu: Pesan (Stimulus, S), Komunikan (Organisms, O) dan Efek (Respons, R).

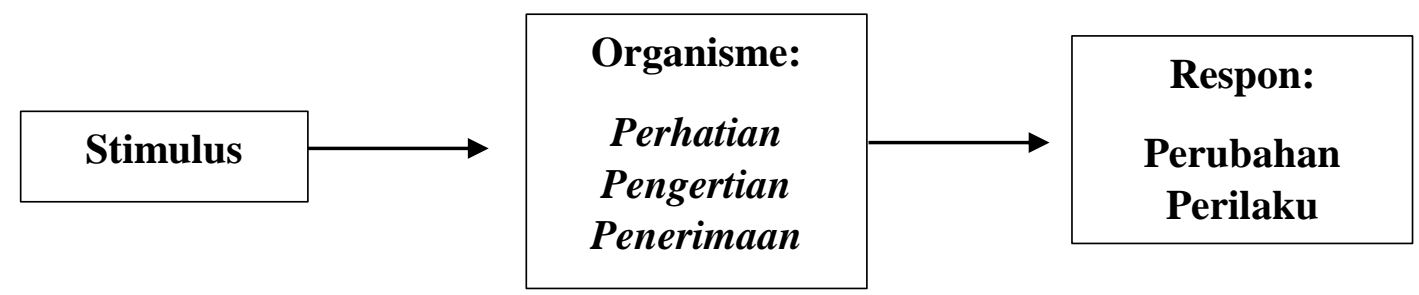

\section{Gambar 1. Skema Model S-O-R}

\section{METODE PENELITIAN}

Penelitian ini menggunakan metode kuantitatif karena berkaitan dengan pengukuran seberapa besar pengaruh komunikasi NCTzen Indonesia terhadap Perilaku untuk Memilih NCT Dream di acara Musik Mingguan. Dengan kata lain, penelitian ini menjelaskan hubungan antara dua variabel. Penelitian ini membutuhkan responden sebanyak 100 orang dengan karakteristik merupakan followers twitter nctconfess dan merupakan penggemar NCT Dream.

Untuk mendapatkan data tentu diperlukan sumber data yang valid yakni followers twitter nctconfess yang melakukan voting saat masa promosi NCT Dream. Teknik pengumpulan data yang digunakan adalah kuesioner melalui media google form yang disebarkan melalui fitur menfess pada akun twitter nctconfess. Data di peroleh dari jawaban kuesioner yang disebarkan pada jumlah sampel sebanyak 100 orang menggunakan teknik nonprobability sampling dengan purposive sampling melalui pertimbangan yaitu merupakan penggemar NCT Dream dan followers aktif akun nctconfess. 100 orang sampel didapatkan dengan perhitungan rumus:

43 | Indah Purnama Sari et al : Pengaruh Komunikasi NCTzen Indonesia Terhadap Perilaku Memilih ... 


$$
\mathrm{n}=\frac{N}{N d 2+1}
$$

Keterangan:

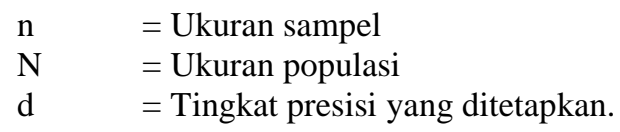

Populasi dari followers media sosial twitter nctconfess sebanyak 94.900 akun saat diakses tanggal 4 Oktober 2019. Presisi ditetapkan antara 10\% dengan tingkat kepercayaan 90\%, maka besarnya sampel adalah

$$
\begin{gathered}
n=\frac{94.900}{94.900 \times(0,1)^{2}+1} \\
n=99,8947
\end{gathered}
$$

Keterangan:

n dibulatkan menjadi 100 responden.

Berdasarkan tinjauan teori dan konsep yang telah dipaparkan sebelumnya, terdapat indikator-indikator dari masing-masing variable yakni variable bebas Komunikasi NCTzen Indonesia dan variable terikat Perilaku

\begin{tabular}{|c|c|c|c|c|c|}
\hline NO & Pernyataan Variabel X (Komunikasi NCTzen Indonesia) & SS & $\mathrm{S}$ & $\mathrm{KS}$ & TS \\
\hline \multicolumn{2}{|r|}{ Persuasif } & 4 & 3 & 2 & 1 \\
\hline 1. & Anda mengajak followers nctconfess melakukan voting & & & & \\
\hline 2. & Anda mengingatkan followers nctconfess untuk voting setiap hari & & & & \\
\hline 3. & $\begin{array}{l}\text { Anda mengajak followers nctconfess untuk streaming Music "Video Boom" } \\
\text { setiap hari }\end{array}$ & & & & \\
\hline 4. & $\begin{array}{l}\text { Anda mengajak followers nctconfess untuk mendukung kemenangan NCT } \\
\text { Dream }\end{array}$ & & & & \\
\hline \multicolumn{2}{|r|}{ Informasi } & & & & \\
\hline 5. & Anda memberikan informasi mengenai voting & & & & \\
\hline 6. & Anda memberikan atau menyebarkan tutorial menggunakan aplikasi starplay & & & & \\
\hline 7. & $\begin{array}{l}\text { Anda menyebarkan link untuk melakukan voting melalui menfess ataupun } \\
\text { kolom komentar pada akun nctconfess }\end{array}$ & & & & \\
\hline \multicolumn{2}{|r|}{ Percakapan } & & & & \\
\hline 8. & Nctconfess menjadi sumber informasi anda saat masa promosi NCT Dream & & & & \\
\hline 9. & Anda aktif memberikan komentar pada menfess mengenai voting NCT Dream & & & & \\
\hline 10 . & $\begin{array}{l}\text { Anda sering melakukan mention untuk menanggapi followers lain yang } \\
\text { bertanya seputar voting }\end{array}$ & & & & \\
\hline
\end{tabular}
Memilih NCT Dream, maka, dapat di pecah menjadi beberapa pernyataan sebagai berikut:

Tabel 1 Pernyataan Variabel $X$ 


\begin{tabular}{|c|l|l|l|l|}
\hline NO & \multicolumn{1}{|c|}{ Pernyataan Variabel X (Komunikasi NCTzen Indonesia) } & SS & KS & TS \\
\hline 11. & Anda turut meramaikan tagar atau hashtag \#BOOM1stWIN & & & \\
\hline \multicolumn{1}{|c|}{ Penerimaan } & & & \\
\hline 12. & Anda menerima ajakan voting untuk NCT Dream melalui menfess & & & \\
\hline 13. & Anda menerima tutorial melakukan voting dari menfess & & & \\
\hline 14. & Anda mendownload aplikasi starplay untuk voting NCT Dream & & & \\
\hline 15. & Anda streaming music video "Boom" setiap hari & & \\
\hline 16. & Anda melihat menfess yang berisi ajakan untuk voting & & \\
\hline 17. & Anda melihat menfess yang berisi tutorial voting & & \\
\hline 18. & Anda menanggapi menfess mengenai voting untuk NCT Dream & & \\
\hline 19. & Anda baru tahu cara memvoting melalui aplikasi starplay dari menfess & & \\
\hline 20. & Anda mengikuti perkembangan vote NCT Dream selama masa promosi & & & \\
\hline 21 & Anda sangat ingin memenangkan NCT Dream saat masa promosi kali ini & & \\
\hline
\end{tabular}

\section{Tabel 2 Pernyataan Variabel Y}

\begin{tabular}{|c|l|c|c|c|}
\hline NO & \multicolumn{1}{|c|}{ Pernyataan Variabel Y (Perilaku Memilih) } & SS & KS & TS \\
\hline 1. & Anda secara sadar melakukan voting karena anda adalah NCTzen & & & \\
\hline 2. & Anda melakukan voting karena ada pengaruh dari menfess & & & \\
\hline 3. & Anda Memvoting NCT Dream karena lagunya bagus & & & \\
\hline 4. & Anda memvoting NCT Dream karena koreografinya unik & & & \\
\hline 5. & $\begin{array}{l}\text { Anda Memvoting NCT Dream karena gaya berpakaian dan gaya rambutnya } \\
\text { cocok dengan lagunya }\end{array}$ & & & \\
\hline 6. & Anda Memvoting NCT Dream karena caranya mudah & & \\
\hline 7. & Anda merasa malu apabila tidak memvoting NCT Dream & & \\
\hline 8. & Followers nctconfess mempengaruhi anda ketika memvoting NCT Dream & & & \\
\hline 9. & Anda memilih NCT Dream karena merasa bertanggung jawab atas NCTzen & & & \\
\hline 10. & Anda menerima tutorial voting dari menfess & & & \\
\hline 11. & Anda menerima link voting dari menfess & & & \\
\hline 12. & Anda menerima informasi seputar voting melalui menfess & & \\
\hline 13. & Anda melakukan voting karena ada ajakan mass voting dari rekan followers & & & \\
\hline
\end{tabular}




\begin{tabular}{|c|l|l|l|l|l|}
\hline 14. & Anda melakukan voting lebih dari sekali dalam seminggu & & & \\
\hline 15. & Anda memvoting NCT Dream karena NCT Dream memiliki reputasi yang baik & & & & \\
\hline
\end{tabular}

Pengukuran data menggunakan skala Likert, karena skala likert dalam Sandjaja dan Heriyanto (2011) menuntut jawaban responden dalam bentuk skala bertingkat. Skala ini meminta responden menunjukkan tingkat persetujuan dan ketidaksetujuannya terhadap serangkaian pernyataan tentang objek yang diajukan oleh peneliti dengan menggunakan kata-kata: 4. Sangat Setuju (SS), 3. Setuju (S), 2. Kurang Setuju (KS), 1. Tidak Setuju (TS).

\section{HASIL DAN PEMBAHASAN}

Berdasarkan hasil kuesioner maka ditemukan beberapa karakteristik responden dimana 58\% dari responden berusia dalam rentang 15 - 20 tahun. Domisili pulau Jawa mendominasi sekitar 50\% responden, diikuti oleh wilayah Jabodetabek sebesar 32\% responden, kota-kota di pulau Sumatera 10\%, kota-kota di pulau Kalimantan $6 \%$ dan kota-kota di Sulawesi 2\%. Hal ini sudah dapat mewakili variable X Komunikasi NCTzen Indonesia karena sudah mewakili hampir seluruh wilayah di Indonesia.

\section{Uji Korelasi}

Uji korelasi dilakukan untuk menguji hubungan antara variabel X (Komunikasi NCTzen Indonesia) dengan variable Y (Perilaku Memilih NCT Dream). Koefisien korelasi antarvariabel dilakukan dengan media SPSS. Hasil uji korelasi penelitian ini adalah :

Tabel 3 Uji Korelasi Spearman's Rho Correlations

\begin{tabular}{|c|c|c|c|c|}
\hline & & & KOMKEL & PERILAKU \\
\hline \multirow{6}{*}{ Spearman's rho } & \multirow{3}{*}{ KOMKEL } & Correlation Coefficient & 1.000 & $.631^{* *}$ \\
\hline & & Sig. (2-tailed) & & .000 \\
\hline & & $\mathrm{N}$ & 100 & 100 \\
\hline & \multirow{3}{*}{ PERILAKU } & Correlation Coefficient & $.631^{* *}$ & 1.000 \\
\hline & & Sig. (2-tailed) & .000 & \\
\hline & & $\mathrm{N}$ & 100 & 100 \\
\hline
\end{tabular}

Sumber: Data diolah melalui SPSS 21

Berdasarkan tabel 3, didapatkan nilai korelaso sebesar 0,631. Nilai tersebut memiliki hubungan yang kuat berdasarkan spearman rank karena berada pada rentang 0,600 - 0,799. Maka disimpulkan bahwa antara komunikasi NCTzen Indonesia dengan Perilaku Memilih memiliki hubungan yang kuat.

Hasil tersebut sesuai dengan teori yang digunakan yaitu teori $\mathrm{S}-\mathrm{O}-\mathrm{R}$ dimana respon yang diberikan oleh NCTzen yaitu melakukan voting atau memilih NCT Dream pada masa promosi sebagai bentuk respon dari stimulus yang dilakukan oleh NCTzen Indonesia di akun twitter nctconfess. Sesuai dengan teori S-O-R semakin banyak stimulus yang diterima oleh NCTzen Indonesia melalui menfess akan lebih mudah terjadi perubahan perilaku NCTzen tersebut. Hal ini terlihat melalui keputusan NCTzen Indonesia sebagai followers twitter nctconfess melakukan voting setelah menerima banyak menfess yang berisi informasi berupa voting untuk NCT Dream. Hal tersebut sejalan dengan teori S-O-R dimana perubahan perilaku dapat terjadi apabila pesan yang disampaikan mampu menumbuhkan motivasi sehingga komunikan cepat menerima pesan yang diterima dan terjadi perubahan perilaku yakni memilih NCT Dream. Melalui teori ini, dapat diketahui sebuah kelompok yang 
terbentuk melalui media sosial atau kelompok virtual tetap bisa menerima stimulus dengan baik dan dapat mempengaruhi anggota kelompok lainnya sehingga merubah perilaku anggota lainnya.

\section{Uji Koefisien Determinasi}

Uji koefisien determinasi bertujuan untuk mengkur seberapa besar pengaruh yang dihasilkan oleh variable $\mathrm{X}$ (Komunikasi Kelompok NCTzen Indonesia) terhadap variable Y (Perilaku Memilih). Rumus untuk menghitung uji koefisien determinasi ini adalah sebagai berikut :

$$
K d=R^{2} \times 100 \%
$$

\section{Keterangan}

$\mathrm{Kd}$ : Koefisien Determinasi

R : Koefisien Korelasi

Maka,

$$
\begin{aligned}
\mathrm{Kd} & =0,631^{2} \times 100 \% \\
& =0,3981 \times 100 \% \\
& =39,81 \%
\end{aligned}
$$

Berdasarkan perhitungan koefisien determinasi diketahui nilai $\mathrm{R}=0,631$ dan $\mathrm{R}^{2}=39,81 \%$. Maka disimpulkan hubungan Perilaku Memilih (variable Y) dipengaruhi oleh Komunikasi NCTzen Indonesia (variable X).

\section{Uji t}

Uji t dilakukan untuk melihat apakah variable X Komunikasi NCTzen Indonesia berpengaruh secara signifikan terhadap variable $\mathrm{Y}$

Tabel 4 Uji t

Coefficients $^{\mathbf{a}}$

\begin{tabular}{|ll|l|l|l|l|l|}
\hline \multicolumn{2}{|l|}{ Model } & \multicolumn{2}{|l|}{ Unstandardized Coefficients } & $\begin{array}{l}\text { Standardized } \\
\text { Coefficients }\end{array}$ & $\mathrm{t}$ & Sig. \\
\cline { 3 - 5 } & $\mathrm{B}$ & Std. Error & Beta & & \\
\hline \multirow{2}{*}{1} & (Constant) & 19.915 & 4.222 & & 4.717 & .000 \\
& KOMKEL & .443 & .058 & .613 & 7.671 & .000 \\
\hline
\end{tabular}

a. Dependent Variable: PERILAKU

Berdasarkan tabel diatas, nilai signifikansi diperoleh sebesar 0,000 dimana 0,000<0,05 sehingga disimpulkan variable $\mathrm{X}$ berpengaruh terhadap variable $\mathrm{Y}$. nilai t pada hasil tabel diatas diketahui thitung sebesar 7.671 dimana $7.671>\mathrm{t}$ tabel 1,984. Penentuan signifikansi $\mathrm{t}$ tabel berdasarkan penghitungan df $=\mathrm{n}-2$ yatu 100-2 = 98 dengan tingkat sgnifikansi 0,05 maka didapatkan angka 1,984. Kesimpulannya, komunikasi NCTzen Indonesia berpengaruh terhadap perilaku memilih

\section{KESIMPULAN}

Hasil penelitian menjelaskan bahwa terdapat pengaruh yang kuat dari komunikasi NCTzen Indonesia terhadap perilaku memilih. Dan untuk menjawab pertanyaan penelitian tentang seberapa besar pengaruh komunikasi NCTzen Indonesia terhadap perilaku memilih (survey pada folowers akun twitter nctconfess) setelah dilakukan penghitungan data melalui media SPSS, disimpulkan:

47 | Indah Purnama Sari et al : Pengaruh Komunikasi NCTzen Indonesia Terhadap Perilaku Memilih ... 
a. Berdasarkan hasil uji korelasi, terdapat pengaruh yang kuat dari komunikasi NCTzen Indonesia terhadap perilaku memilih. Hal ini dapat terlihat dari seberapa intens dalam sehari menfess yang berkaitan tentang voting dan dapat dibuktikan kuatnya pengaruh dari kemenangan NCT Dream.

b. Uji koefisien determinasi menunjukkan hasil 39,81\% hubungan yang signifikan antara komunikasi NCTzen Indonesia dengan perilaku memilih. Meskipun 39,81\% terlihat kecil namun tetap ada hubungan yang signifikan untuk membuktikan bahwa perubahan perilaku disebabkan oleh komunikasi NCTzen. Dan sebanyak 60,19\% lainnya berasal dari faktor lain yang tidak diteliti oleh peneliti seperti reputasi NCT Dream, keunikan koreografi, music yang disukai, gaya berpakaian NCT Dream.

c. Berdasarkan uji t, Ha diterima dan Ho ditolak karena terdapat pengaruh dari komunikasi NCTzen Indonesia terhadap perilaku memilih.

\section{DAFTAR PUSTAKA}

\section{Buku:}

Bungin, Burhan. (2005). Metodologi Penelitian Kuantitatif. Jakarta: Kencana

Effendy, Onong Uchjana. (2004). Dinamika Komunikasi. Bandung: PT Remaja Rosdakarya.

Effendy, Onong Uchjana. (2018). Ilmu Komunikasi teori dan Praktek. Bandung: PT. Remaja Rosdakarya.

Eunson, Beden. 2012. C21 Communicating In The $21^{\text {st }}$ Century $3^{\text {rd }}$ Edition. China: 1010 Printing.

Gamble, Teri Kwal and Michael Gamble. 2002. Communication Works. America: Library of Congress Cataloging in Publication Data.

Hikmat, Mahi M. (2011). Metode Penelitian Dalam Perspektif Ilmu Komunikasi dan Sastra. Yogyakarta: Graha Ilmu

Jenkins, Henry dan David Thorburn. (2003). Rethinking Media Change The Aesthetics of Transition. Amerika Serikat: Graphic Composition

Littlejohn, Stephen W. 1996. Theories of Human Communication, Edisi ke-5. Belmont: California, Wadsworth.

Maulana, Herdiyan dan Gumgum Gumelar. (2013). Psikologi Komunikasi dan Persuasi. Jakarta: Akademia Permata

Moeloeng, Lexy J. 2018. Metodologi Penelitian Kualitatif. Bandung: PT Remaja Rosdakarya

Mulyana, Deddy. (2005). Pengantar Ilmu Komunikasi.

Nasrullah, Rulli. 2012. Komunikasi Antarbudaya Di Era Siber. Jakarta: Kencana

Nurudin. (2017). Ilmu Komunikasi Ilmiah dan Populer. Jakarta: PT. Rajawali Pers

Ridwan, Aan. 2016. Komunikasi ANtarbudaya. Bandung: CV Pustaka Setia

Rohim, Syaiful. (2016. Teori Komunikasi Perspektif, Ragam, dan Aplikasi. Jakarta: PT. Rineka Cipta

Sandjaja, B dan Albertus Heriyanto. (2006). Panduan Penelitian. Jakarta: Prestasi Pustaka

Sugiyono. (2015). Metode Penelitian Pendidikan: Pendekatan Kuantitatif, Kualitatif, dan R\&D. Bandung: Alfabeta

Jurnal:

Choi, Seong Cheol, Xanat Meza Vargas dan Hanwoo Park. (2014). South Korean Culture Goes Latin America: Social Network Analysis of KPOP Tweets in Mexico. Korea Science Internatioal Journal of Contents. 10(1). 
Darmawan, Awan. (2014). Perilaku Masyarakat dalam Mengelola Sampah di Kota Bima Nusa Tenggara Barat. Jurnal Pembangunan Wilayah dan Kota. 10 (2), 175-176.

Kurniawan, Dani. (2018). Komunikasi Model Laswell dan Stimulus-Organism-Response dalam Mewujudkan Pembelajaran Menyenangkan. Jurnal Komunikasi Pendidikan, 2(1). 2549-4163

Muhammad, Rafki dan Rouli Manalu. (2015). Analisis Pemanfaatan Virtual Community Sebagai Media Komunikasi Kelompok Melalui Sosial Media. Jurnal Ilmu Komunikasi UNDIP

Permassanty, Tanty Dewi dan Muntiani. (2018). Strategi Komunikasi Komunitas Virtual dalam Mempromosikan Tangerang Melalui Media Sosial. Jurnal Penelitian Komunikasi, 21(2), 1410-8291

Salainty, Falyana R, Adelien Walandouw, Sintje Rondonuwu. (2015). Pengaruh Permainan Internet terhadap Perilaku Remaja di Kelurahan Karombasan Utara. Jurnal Actra Diurna, Vol 4(1).

Saleh, Gunawan, Ribka Pitriani. (2018). Pengaruh Media sosial Instagram dan Whatsapp terhadap Pembentukan Busaya "Alone Together". Jurnal Komunikasi, Vol 10 (2). 2085-1979.

Sosiawan, Edwi Arief. (2011). Penggunaan Situs Jejaring Sosial sebagai Media Interaksi dan Komunikasi di Kalangan Mahasiswa. Jurnal Ilmu Komunikasi, 9(1). 60-75

Watie, Errika Dwi Setya. (2011). Communication and Social Media.The Messenger, 3(1), 2527-2810.

\section{Website:}

Kompas.com. (2019). APJII: Jumlah Pengguna Internet di Indonesia Tembus 171Juta Jiwa. https://tekno.kompas.com/read/2019/05/16/03260037/apjii-jumlah-pengguna-internet-di-indonesiatembus-171-juta-jiwa. Diakses pada tanggal 4 Oktober 2019.

Wearesocial.com. (2019). The State of Digital In April 2019: All The Numbers You Need To Know. https://wearesocial.com/blog/2019/04/the-state-of-digital-in-april-2019-all-the-numbers-you-need-toknow. Diakses pada 4 Oktober 2019

Katadata.com. (2019). Indonesia Peringkat Kelima Dunia dalam Jumlah Penggunaan Internet. https://databoks.katadata.co.id/datapublish/2019/09/11/indonesia-peringkat-kelima-dunia-dalamjumlah-pengguna-internet Di akses pada 4 Oktober 2019

www.kpopfans.net diakses pada 4 Oktober 2019

www.kominfo.go.id diakses pada 4 Oktober 2019

www.korea.net/AboutKorea diakses pada 4 Oktober 2019

www.twitter.com/nctconfess diakses pada 4 Oktober 2019

www.allkpop.com diakses 2 Desember 2019

http://nctdream.smtown.com/ diakses pada 3 Desember 2019

Soompi.com. (2016). NCT Reveals Final Member of NCT Dream. https://www.soompi.com/article/887935wpp/nct-shares-1st-teaser-image-nct-dream diakses pada 3 Desember 2019.

Detik.com. (2016). NCT Dream Debut Perdana dengan 'Chewing Gum'. https://hot.detik.com/kpop/d3284316/nct-dream-debut-perdana-dengan-chewing-gum diakses pada 3 Desember 2019

Soompi.com. (2017). NCT Dream Announces Comeback With $1^{\text {st }}$ Single Album. https://www.soompi.com/article/944779wpp/nct-dream-announces-comeback-1st-single-album diakses pada 8 Desember 2019

Allkpop.com (2017). Comeback! NCT Dream My First And Last Win, NCT First https://www.allkpop.com/forum/threads/comeback-nct-dream-my-first-and-last-first-win-nct-firstwin.52786/. Diakses pada 8 Desember 2019

49 | Indah Purnama Sari et al : Pengaruh Komunikasi NCTzen Indonesia Terhadap Perilaku Memilih ... 
Detik.com. (2017). Hore! NCT Dream Comeback 17 Agustus dengan 'We Young'. https://hot.detik.com/kpop/d3591992/hore-nct-dream-comeback-17-agustus-dengan-we-young. Diakses pada 8 Desember 2019

MTV.com. (2018). Bazzi Wrote NCT Dream's New Single 'We Go Up' and It's A Total Earworm. http://www.mtv.com/news/3098557/nct-dream-bazzi-we-go-up/. Diakses pada 9 Desember 2019

Billboard.com. (2018), NCT Dream Release Video for Bazzi Penned 'We Go Up': Watch. https://www.billboard.com/articles/columns/k-town/8473106/nct-dream-we-go-up-video. Diakses pada 9 Desember 2019

CNNINDONESIA.com. (2019). Pendewasaan NCT Dream dalam Video Musik 'BOOM'. https://www.cnnindonesia.com/hiburan/20190726122508-227-415740/pendewasaan-nct-dream-dalamvideo-musik-boom. Diakses pada 9 Desember 2019 